\title{
Muscle protein metabolism in neonatal alloxan- administered rats: effects of continuous and intermittent swimming training
}

\author{
Carla Ribeiro*, Lucieli T Cambri, Rodrigo A Dalia, Michel B Araújo, Ana C Ghezzi, Leandro P Moura,
} Gustavo G Araújo, Jose D Botezelli and Maria AR Mello

\begin{abstract}
Background: This study aimed to examine the effects of intermittent and continuous swimming training on muscle protein metabolism in neonatal alloxan-administered rats.

Methods: Wistar rats were used and divided into six groups: sedentary alloxan (SA), sedentary control (SC), continuous trained alloxan (CA), intermittent trained alloxan (IA), continuous trained control (CC) and intermittent trained control (IC). Alloxan (250 mg/kg body weight) was injected into newborn rats at 6 days of age. The continuous training protocol consisted of 12 weeks of swimming training in individual cylinder tanks while supporting a load that was $5 \%$ of body weight; uninterrupted swimming for $1 \mathrm{~h} /$ day, five days a week. The intermittent training protocol consisted of 12 weeks of swimming training in individual cylinder tanks while supporting a load that was $15 \%$ of body weight; 30 s of activity interrupted by $30 \mathrm{~s}$ of rest for a total of 20 min/ day, five days a week.
\end{abstract}

Results: At 28 days, the alloxan animals displayed higher glycemia after glucose overload than the control animals. No differences in insulinemia among the groups were detected. At 120 days, no differences in serum albumin and total protein among the groups were observed. Compared to the other groups, DNA concentrations were higher in the alloxan animals that were subjected to continuous training, whereas the DNA/protein ratio was higher in the alloxan animals that were subjected to intermittent training.

Conclusion: It was concluded that continuous and intermittent training sessions were effective in altering muscle growth by hyperplasia and hypertrophy, respectively, in alloxan-administered animals.

Keywords: DMT2, exercise training, protein synthesis, hypertrophy muscle

\section{Background}

Diabetes is a group of metabolic disorders characterized by hyperglycemia resulting from defects in insulin secretion or insulin action [1-3], which leads to changes in carbohydrate, fat and protein metabolism. The chronic hyperglycemia of diabetes is associated with dysfunction and failure of various organs and tissues, including muscle. Type 1 diabetes mellitus (T1DM) is a multifactorial autoimmune disease in which susceptibility is determined by a combination of genetic and environmental factors $[2,4]$. The disease is characterized by chronic

\footnotetext{
*Correspondence: Carla_ef_rc@yahoo.com.br

São Paulo State University - UNESP, Physical Education Department, Av: 24-A, 1515 Bela Vista. CEP: 13506-900 Rio Claro - São Paulo - Brazil
}

hyperglycemia and by the development of specific vascular alterations $[2,5]$. In this diabetes type, there is a $\mathrm{T}$ cell-mediated destruction of the insulin secreting $\beta$-cells of the pancreatic islets. Type 2 diabetes (T2DM) accounts for approximately 90 to $95 \%$ of diabetics and may be promoted by several factors, such as obesity, a high calorie diet and physical inactivity $[2,6]$. T2DM is characterized by a combination of insulin resistance and a compensatory response to inadequate insulin secretion, which leads to the characteristic hyperglycemia $[2,7]$. Currently, it has been observed that T2DM changes the serum levels of several amino acids that may contribute to disturbances in insulin secretion and action [8].

\section{()


It is currently accepted that physical training is of great importance in improving the level of physical fitness and quality of life. Exercise has been increasingly recommended in the prevention and rehabilitation of cardiorespiratory diseases, osteoporosis, diabetes, and in combating stress [9-11]. Particularly, in the treatment of T2DM, regular physical exercise at different intensities improves glucose tolerance and reduces insulin resistance. However, the literature lacks direct evidence on the preventive effect of exercise on the development of T2DM; in particular, investigations into the effect of effort intensity and different exercise protocols is lacking because this type of research is more difficult to conduct in humans. In this context, animal models are more suitable for the study of these issues.

Beta-cytotoxic chemical agents have been widely and successfully employed as experimental model for studies of the diabetes-induced complications successfully [12-14] Alloxan is a drug widely used as a diabetes experimental model. This drug, presents an effect selectively toxic on the beta cells from the islets of Langerhans in the pancreas [15]. It is known that the application of diabetogenic drugs in adult animals produces severe diabetes and in many cases requires the use of insulin when rats need to survive for a longer period of time [16], but in newborn animals a few days after the drug administration occurs a decrease in pancreatic insulin production. From this phase on, $\beta$ cells regenerated spontaneously, by replication and/or neogenesis [17], reaches $50 \%$ of the value presented for control animals [18].

Portha et al. [18] described an experimental model of neonatal diabetes in Wistar rats by the application of streptozotocin on the day of birth. In this model, it was demonstrated that hyperglycemia is transitory. The blood glucose levels normalize after the first week of life, with restoration of insulin production and $\beta$-cell mass. That study features a T2DM model in rats, in which the experimental animals presented good survival [18]. Takada et al. [19] using the neonatal streptozotocin model - administered in the animals on the 5th day of life, showed that after 12 weeks of the experiment the pancreatic insulin content decreased and impaired glucose tolerance. Moreover, in another study using the streptozotocin application as an experimental model in which it was administrated at 4 days after birth, it was observed, after three weeks of streptozotocin injection, a $72 \%$ decrease in pancreatic insulin stores without change in pancreatic glucagon stores [20].

Later, Kodama et al. [21] developed another model that replaced streptozotocin with alloxan. In that study, alloxan was administered on the 2th, 4th or 6th days of life. When analyzed at 60 days of life, the rats that received alloxan on the 2 th of life showed blood glucose levels in the fed state that were slightly higher than those of the control rats, whereas the rats that received the drug on the 4th and 6th days showed blood glucose levels that were significantly higher than those of the controls. The authors considered a useful model for studies on chronic complications of diabetes. However, they emphasized that more studies were needed to determine whether the alloxan-administered neonatal rats showed characteristics of T2DM, as was seen in the streptozotocin neonatal model.

Oliveira et al. [22] examined the fasting plasma glucose and glucose tolerance in the male rats at 30, 60, and 90 days old after receiving alloxan on the 2nd day of life. Fasting glucose was not different from control rats at any time. At 90 days the static insulin secretion by the pancreatic islets of the animals was similar among the groups at 2.8 and $5.6 \mathrm{mM}$ of glucose, but the pancreatic insulin content of the alloxan group was smaller than the control group [17]. Contarteze et al. [23] showed that these animals presented higher blood glucose levels after an oral glucose load than controls. Similar results were reported by Cimbiz et al. [3], in which the alloxan group presented higher blood fasting glucose levels than the control group. Ribeiro et al. [24], during a glucose tolerance test in rats that received alloxan on the 6th day of life, also showed higher blood glucose values in the alloxan group compared to the control group at 28 days old and 60 days old. Moreover at 60 days old, it was observed lower insulin secreted by the isolated islets in relation to the control group for the glucose concentration of $16.7 \mathrm{mM}$. Taken together, these data show that the neonatal alloxan administration model illustrates interesting features for studying the role of exercise in preventing and treating diabetes. Studies using different training protocols in the prevention and treatment of T2DM are scarce especially in relation to protein metabolism.

A study in rats that were subjected to the neonatal application of alloxan and continuous swimming training at moderate intensity showed that the total serum protein and skeletal muscle protein content did not change after 8 weeks of exercise training [22]. Luciano and Mello [25], using the alloxan model of diabetes in adult rats, did not observe any differences in total protein and albumin concentrations between the groups after 4 weeks of moderate continuous swimming training.

In adult alloxan-mediated diabetic rats Leme et al. [26], there were no changes in serum albumin after 8 weeks of continuous swimming exercise at an intensity of $90 \%$ the maximal lactate steady state. On the other hand, non-diabetic rats that were subjected to highintensity intermittent training showed higher expression of GLUT-4 protein in skeletal muscle [27]. Fedele et al. 
[28] showed that in contrast to non-diabetic animals, partial pancreatectomy diabetic animals did not show increased protein synthesis after acute resistance training. Therefore, it seems that both continuous and intermittent training may play important roles in the prevention and treatment of diabetes, but further studies are needed to characterize the intensity and frequency that are best suited to each of these protocols. In this context, the present study aimed to examine the effects of intermittent and continuous training on muscle protein metabolism in neonatal alloxan-administered rats.

\section{Methods}

\subsection{Animals}

The studies were conducted on newborn male Wistar rats that were kept at $25 \pm 1^{\circ} \mathrm{C}$ under a $12 \mathrm{~h} / 12 \mathrm{~h}$ lightdark cycle and fed standard rodent chow and water ad libitum. During breastfeeding, food and water were offered ad libitum to the mothers, and the pups were distributed in litters of eight per dam. All animal experiments were approved by the committee of ethics in animal research, Taubate University-CEEA/UNITAU, under protocol $n^{\circ}$ 019/08.

\subsection{Neonatal alloxan administration}

At 6 days old, after a 15-h fast, the male pups with a body weight of $11.9 \pm 1.2 \mathrm{~g}$ received intraperitoneal alloxan monohydrate (Sigma-Aldrich Inc., St Louis, MO, USA) injections ( $250 \mathrm{mg} / \mathrm{kg}$ body weight) that were dissolved in $0.01 \mathrm{M}$ citrate buffer at $\mathrm{pH} 4.5$ [29]. Vehicleinjected (citrate buffer) rats were used as controls. Immediately, the pups were distributed so that each mother nursed eight of them.

\subsection{Experimental groups}

At 28 days old, the animals were randomly divided into six groups of 10 rats each and remained under observation until 120 days old (Figure 1):

- Sedentary Control (SC): citrate buffer-injected rats that were not subjected to exercise training

- Continuous Training Control (CC): citrate bufferinjected rats that were subjected to the continuous exercise training protocol.

- Intermittent Training Control (IC): citrate bufferinjected rats that were subjected to the intermittent exercise training protocol.

- Sedentary Alloxan (SA): alloxan-injected rats that were not subjected to exercise training.

- Continuous Training Alloxan (CA): alloxan-injected rats that were subjected to the continuous exercise training protocol.

- Intermittent Training Alloxan (IA): alloxan-injected rats that were subjected to the intermittent exercise training protocol.

\subsection{Exercise training}

The rats were initially adapted to the water to reduce the stress caused by the physical exercise performed in this environment. The adaptation consisted of the following sequence, which was followed by the initiation of training: 5, 10, and $15 \mathrm{~min}$ in shallow water; 5, 10, and $15 \mathrm{~min}$ in deep water; $5 \mathrm{~min}$ with a bag tied to the thorax; and 5, 10, and 15 min with a bag containing a load of $3 \%$ of body weight tied to the thorax. Between weaning and 120 days of age, the animals that were trained with the continuous exercise protocol were subjected to 1 hour per day, five days a week, of uninterrupted swimming in individual cylinder tanks $(25 \mathrm{~cm}$ in diameter $\times 50 \mathrm{~cm}$ in depth) while supporting a load of $5 \%$ of body weight. This intensity corresponds to the aerobic/anaerobic metabolic transition during swimming exercise for rats [30]. Between weaning and 120 days of age, the animals that were trained with the intermittent protocol were subjected to 5 days a week of swimming in individual cylinder tanks $(25 \mathrm{~cm}$ in diameter $\times 50 \mathrm{~cm}$ in depth) for $30 \mathrm{~s}$ interrupted by $30 \mathrm{~s}$ of rest for a total of 20 min per day while supporting a load of $15 \%$ of body weight (adapted from [31]). The water temperature was maintained at $31 \pm 1^{\circ} \mathrm{C}$, which was considered a thermally neutral temperature for rats $[32,33]$. The training protocols consisted of equivalent total weekly training load (WL). According to Araújo et al. [34], WL represents the total of stimuli of training obtained by the product of the exercise time $(\mathrm{t})$ and the intensity (\%). Therefore, in this study, the continuous training protocol, in which $\mathrm{WL}=60 \mathrm{~min} \times 5 \%=300$, was equivalent to the intermittent training protocol, in which $\mathrm{WL}=20 \mathrm{~min} \times 15 \%=300$.

\subsection{In vivo Evaluations}

The body weight, food and water intake of all the animals were registered once a week from weaning on. They were also evaluated for fasting and non-fasting blood glucose and insulin levels.

\subsubsection{Blood glucose and insulin}

The diabetogenic effect of alloxan was confirmed when the rats were 28 and 120 days old by the determination of the fasting (after a 12-h fast) and non-fasting (30 min after administration of glucose solution, $2.0 \mathrm{~g}$ [ $\mathrm{kg}$ body weight]-1, into the stomach through a gastric catheter) serum glucose by the oxidase method (Kit glicose Laborlab: CAT n 02200- Guarulhos- SP) and the serum insulin based on ELISA (Kit Insulina- Diagnostic Systems Laboratories INC (DSL), REF: 10-1600, 445 medical Center BLVD, Webster, TX 77598, USA).

\subsection{Biological material collection}

At 120 days of age, biological material was obtained from animals that were sacrificed by decapitation after 


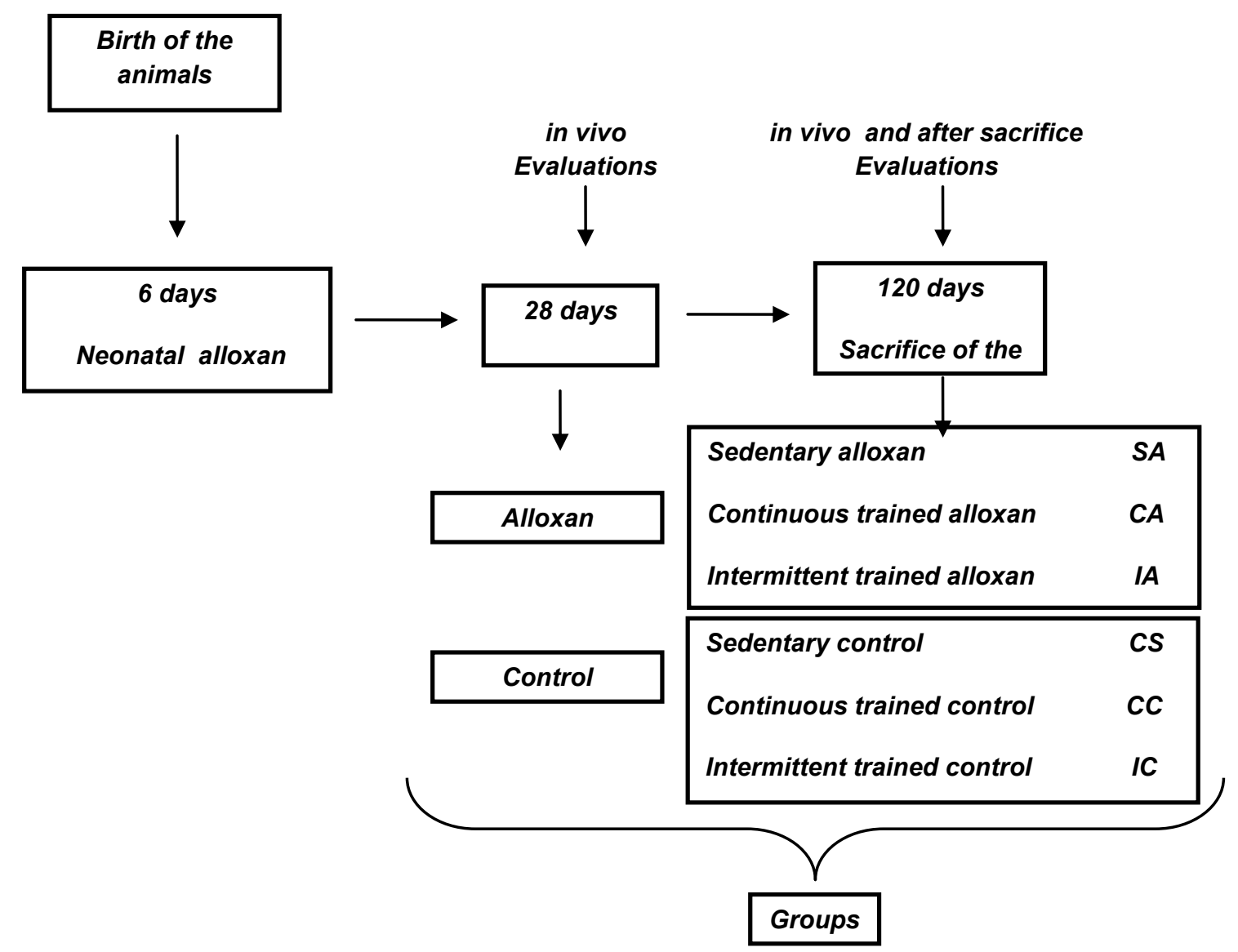

Figure 1 Experimental Design.

deep anesthesia with sodium amobarbital $(15 \mathrm{mg} / \mathrm{kg}$ body weight) without fasting and 48 hours after the last in vivo procedure.

\subsubsection{Blood}

Blood samples were collected to verify the concentrations of glucose (Kit glicose - Laborlab: CAT n 02200Guarulhos-SP), total protein and albumin by spectrometry (total protein Kit - Laborlab: CAT n ${ }^{\circ} 03801$ e albumin Kit - Laborlab: CAT n 03802- Guarulhos- SP) and serum insulin by ELISA (Kit Insulina-Diagnostic systems laboratories INC (DSL), REF: 10-1600, 445 medical Center BLVD, Webster, TX 77598, USA).

\subsubsection{Adipose Tissue}

The adipose tissue of the posterior subcutaneous, mesenteric and retroperitoneal regions were removed and weighed for determination of total fat content. Excision of the different fat deposits was carried out according to the description of Cinti [35]

\subsubsection{Gastrocnemius muscle}

Samples of the gastrocnemius muscle were excised for the evaluation of total protein [36] and DNA content [37], to determine the number (DNA) and size (protein/ DNA ratio) of the cells [38].

\subsubsection{Soleus muscle}

2.6.4.1 Protein Synthesis Longitudinal strips from the soleus muscle $(70 \mathrm{mg})$ were preincubated for $30 \mathrm{~min}$ in a RPMI 1640 medium (with glutamine and without red phenol and sodium bicarbonate) that was supplemented with fat-free $0.1 \%$ bovine serum albumin (BSA) and 100 $\mu \mathrm{U}$ ml-1 insulin and saturated with a $95 \% \mathrm{O} 2 / 5 \% \mathrm{CO} 2$ gas mixture. The strips were then transferred to fresh RPMI medium, which contained the same supplements in addition to $0.05 \mathrm{ACi} \mathrm{ml-1} \mathrm{[14C]} \mathrm{phenylalanine,} \mathrm{and}$ incubated for two more hours. At the end of this incubation, the muscle strips were homogenized in 5\% trichloroacetic acid (TCA) and centrifuged at $2000 \mathrm{rpm}$ for $15 \mathrm{~min}$ at $4^{\circ} \mathrm{C}$. TCA-insoluble material was washed three times with 5\% TCA. The resulting precipitate was dissolved for $30 \mathrm{~min}$ in $10 \%$ sodium dodecyl sulfate at room temperature to determine both protein content and the radioactivity incorporated into the muscle protein. Muscle protein content was determined by the folin phenol method [38], and the radioactivity incorporated into the muscle proteins was determined with a liquid scintillation counter. Protein synthesis was calculated by dividing the incorporated radioactivity by the 
specific phenylalanine radioactivity in the incubation medium.

2.6.4.2 Protein Degradation Tyrosine liberation by isolated muscles in the presence of cyclohexamide was employed as the protein degradation index [39]. This method is based on the fact that the amino acid tyrosine is neither synthesized nor degraded by skeletal muscle. Longitudinal strips from the soleus muscle $(70 \mathrm{mg})$ were preincubated in Krebs-Ringer buffer $(\mathrm{NaCl}, 1.2 \mathrm{mmol} / \mathrm{L}$; $\mathrm{KCl}, 4.8 \mathrm{mmol} / \mathrm{L} ; \mathrm{NaHCO} 3,25 \mathrm{mmol} / \mathrm{l} ; \mathrm{CaCl} 2,2.5$ $\mathrm{mmol} / \mathrm{L} ; \mathrm{KH} 2 \mathrm{PO} 4,1.2 \mathrm{mmol} / \mathrm{l}$; MgSO $4,1.2 \mathrm{mmol} / \mathrm{L}$; $\mathrm{pH}$ 7.4) that was supplemented with $5.5 \mathrm{mmol} / \mathrm{L}$ glucose, $1.34 \%$ BSA, 5 AUml-1 insulin, and $5.0 \mathrm{mmol} / \mathrm{L}$ cyclohexamide and saturated with a 95\% O2/5\% CO2 gas mixture. Subsequently, the muscle strips were transferred to fresh medium with the same composition and incubated for two more hours. At the end of the incubation, the samples of the incubation medium were used for tyrosine determination [40].

\subsubsection{Pancreatic Islets}

To measure insulin secretion, groups of five pancreatic islets isolated by collagenase digestion [41] were incubated for $30 \mathrm{~min}$ at $37^{\circ} \mathrm{C}$, in Krebs bicarbonate medium containing glucose $(5,6 \mathrm{mM})$, supplemented with bovine serum albumin $(3 \mathrm{~g} / \mathrm{l})$ and balanced with a mixture of 95\% $\mathrm{O}_{2}-5 \% \mathrm{CO}_{2} ; \mathrm{pH} 7,4$. The solution was then replaced by fresh buffer, and the islets were incubated for a further hour with different glucose concentrations $(2.8,11.1 \mathrm{mM})$. The insulin content of the incubation medium was determined by ELISA (Kit Insulina- Diagnostic Systems Laboratories INC (DSL), REF: 10-1600, 445 medical Center BLVD, Webster, TX 77598, USA).

\subsection{Statistics}

Data analysis was performed using the student $\mathrm{t}$-test or two-way analysis of variance ANOVA followed by Bonferroni post hoc test when appropriate. In all cases, the level of significance was determined at $5 \%(\mathrm{p}<0.05)$.

\section{Results}

Changes in animal body weight (Figure 2A) during the experimental period were analyzed by the weight gain during the experiment, shown in Figure 2B. The IC group had reduced weight gain compared to the SC group, which demonstrates the efficacy of intermittent training in weight control in the control animals. The adipose tissue weight of the retroperitoneal, posterior subcutaneous and mesenteric regions were presented in Figure $3 \mathrm{~A}, \mathrm{~B}$ and Figure 3C, respectively. It was observed significant difference only in the retroperitoneal fat content in which the CC group showed significantly lower values than the IC group.

In Figures $4 \mathrm{~A}$ and $4 \mathrm{~B}$, the values related to food and water intake, respectively, are presented. No significant differences among the groups were observed in these parameters. Table 1 presents the data of the fasting and non-fasting (after glucose overload) serum glucose and insulin levels at 28 days of age. After glucose overload, the alloxan group presented higher serum glucose values than the control group.

Table 2 shows the fasting and non-fasting (after glucose overload) serum glucose and insulin levels at 120 days of age. The IA group presented higher serum glucose values than the IC group after glucose overload.

At 120 days of age it was evaluated the static insulin secretion by the pancreatic islets in response to different glucose concentrations ( 2.8 and $11.1 \mathrm{mM})$ which is presented in the table 3 . It was observed significant differences among the groups. At concentration of $2.8 \mathrm{mM}$ the SA group showed lower values when compared to corresponding control. The same was found in the glucose concentration $11.1 \mathrm{mM}$. Both exercise training protocols counteracted the alterations at $2.8 \mathrm{mM}$ glucose concentration. Total serum protein and albumin levels, DNA content and the protein/DNA ratio in the gastrocnemius muscle are presented in Table 4. When total serum protein and albumin were analyzed, no differences among the groups were observed. In relation to the DNA content of the gastrocnemius muscle, the CA group showed higher values than the IA group. On the other hand, the protein/DNA ratio was higher in the IA group than in the CA group, which indicates higher muscle hypertrophy after intermittent training.

Protein synthesis and degradation in the soleus muscle did not differ among the groups (Table 5).

\section{Discussion}

It is known that insulin has effects on glucose, fat and protein metabolism. Particularly in protein metabolism, insulin increases the intensity of amino acid transport across the cell membrane, which increases the available amino acids for protein synthesis. In diabetes mellitus, due to changes in insulin production and/or action, protein metabolism is altered. In turn, physical exercise promotes muscle protein anabolism, which results in morphological and metabolic adaptations in skeletal muscle.

Currently, it has been observed that high-intensity exercise can effectively increase muscle strength and mass and improve physical performance and functional capacity. Thus, the present study investigated the effects of intermittent and continuous training on protein metabolism in neonatal alloxan-administered rats.

In this study, the weight gain of animals was analyzed, and it was observed that the neonatal alloxan administration did not affect weight gain. Similar results were reported by Ribeiro et al. [24] using the same experimental model used in the present study. 


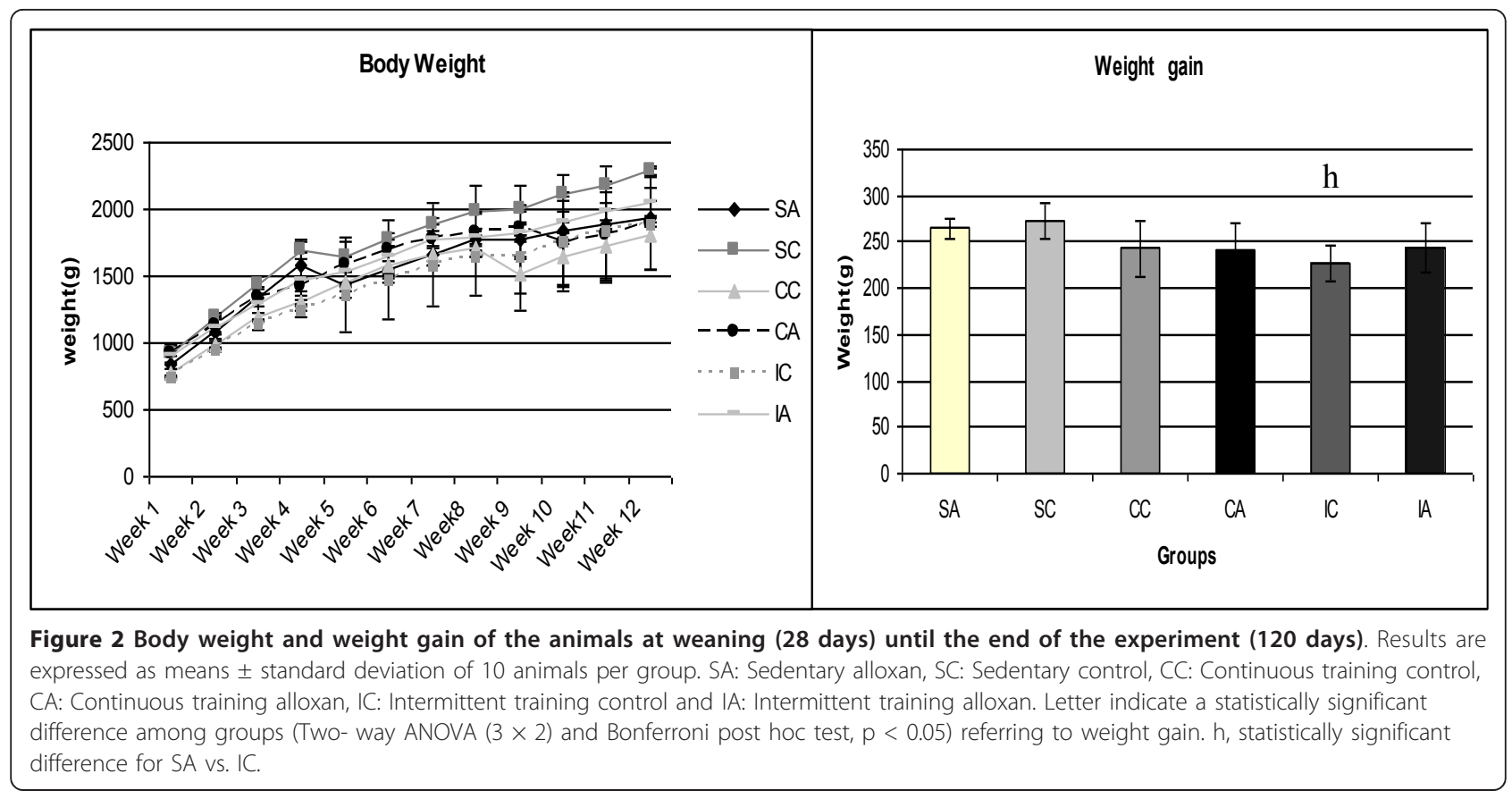

Moreover, the sedentary control group showed higher gains in body weight than the control group that was subjected to the intermittent training protocol, which demonstrates a beneficial effect of this protocol on weight control. Furthermore, it is known that overweight or obesity are risk factors for the onset of T2DM [42]. Studies show that adipose tissue distribution is changed in type 2 diabetes mellitus [43]. Thus this study analyzed the adipose tissue in the retroperitoneal, subcutaneous and mesenteric regions. No difference was found in fat mass in the different regions when compared the groups that received the diabetogenic drug and controls. However, significant difference was found between the control animals after physical training, showing a smaller deposit of retroperitoneal fat in animals that performed continuous training compared to intermittent training. This demonstrates the beneficial effect of exercise to reduce abdominal fat [44] which high risk of developing metabolic complications such as impaired glucose tolerance, insulin resistance [45].

With respect to food and water intake of the animals, no difference was found among the groups, which shows that neonatal alloxan administration did not lead to polyphagia or polydipsia, which are usually observed in adult alloxan-mediated diabetic animals [46].

T2DM leads to glucose intolerance and insulin resistance, therefore, to evaluate changes in glucose homeostasis, the fasting and non-fasting (after glucose overload) serum glucose and insulin levels were determined at 28 and 120 days of age. At 28 days, glucose intolerance, which was indicated by the higher values of glycemia 30 min after the oral glucose overload, was observed to a greater extent in the alloxan group compared to the control group, which confirms the findings of a previous study [23]. At 120 days, glycemia after glucose overload was higher in the intermittent trained alloxan group compared to the corresponding control group, which was evidence for the differences in glucose homeostasis between the alloxan and control groups. After static insulin secretion by the isolated pancreatic islets in response to different glucose concentrations evaluation, it was evident the alloxan effect, because at lower and high glucose concentrations ( 2.8 and $11.1 \mathrm{mM})$ the sedentary alloxan animals had lower insulin secretion compared to the sedentary controls. On the other hand in the Oliveira et al. [22] study, using similar experimental model, no significant difference was found between animals that received the drug in 2 days of age and the control rats in the insulin secretion at different glucose concentrations (2.8 e $16.7 \mathrm{mM}$ ). Furthermore, it was observed in the present study that physical training has an important role in improving insulin secretion. At low glucose concentrations $(2.8 \mathrm{mM})$ both exercise training protocols avoided the decrease in glucose induced insulin secretion caused by alloxan administration. Similar results were described in a previous study where the rats that received alloxan at 2 days of age and performed continuous training had better insulin secretory response compared to the sedentary animals [22].

The growth of organs can be caused by an increase in cell number (hyperplasia), an increase in cell size (hypertrophy) or by both processes simultaneously. The 


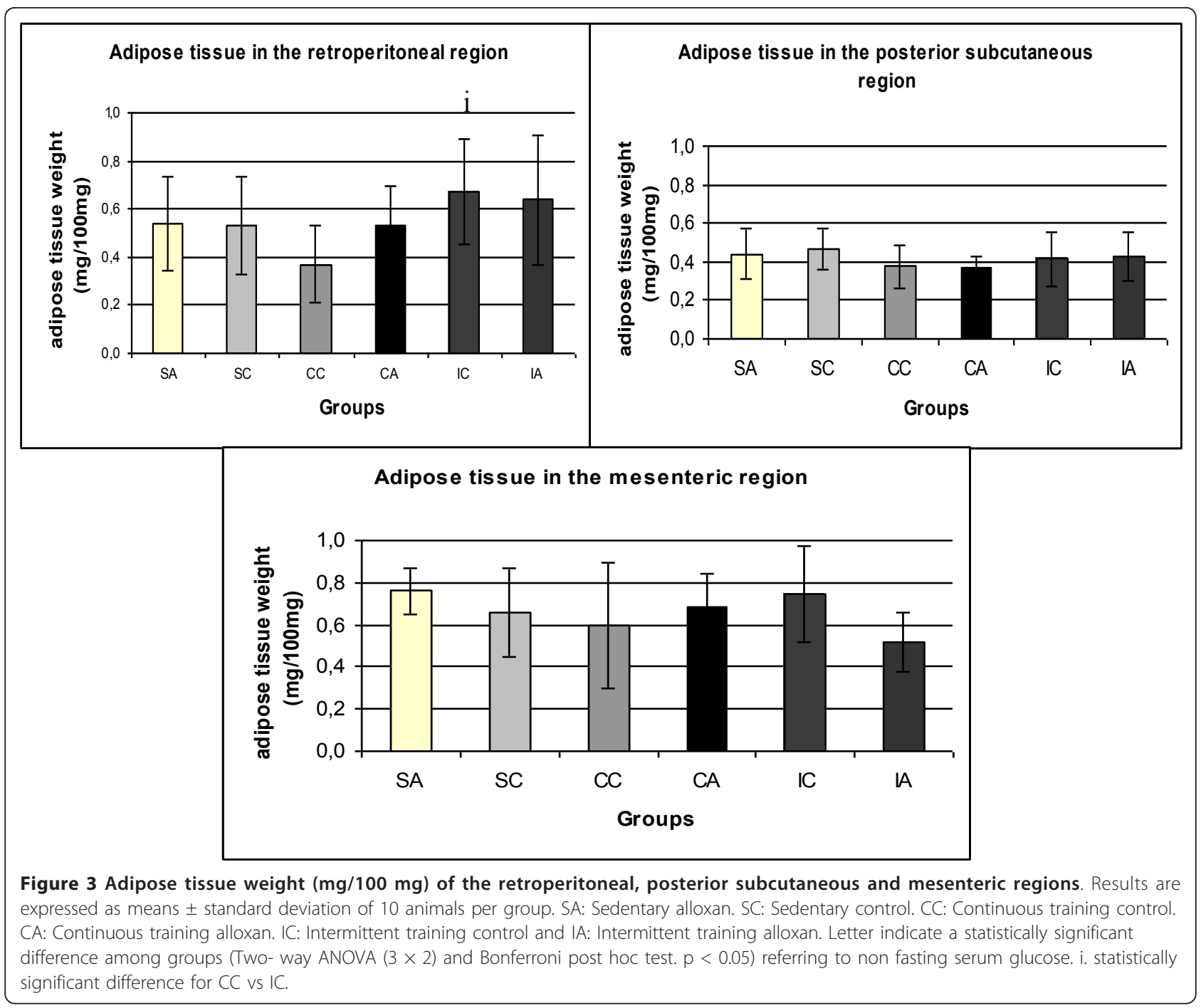

total cell number can be measured, with exceptions, by determining the total DNA content of the organ and dividing by a constant that represents the DNA content per diploid nucleus in the species being studied [38]. Determined the number of cells, the average weight, the protein content and the RNA content per cell, among others, can be assessed by determining the total quantity of each element and dividing by the number of cells. The result can be expressed as weight/DNA, protein/ DNA, RNA/DNA ratios, etc. [38].

An increase in DNA content represents one type of growth: increased cell number; an increase in the weight/DNA, protein/DNA and RNA/DNA ratios represent another aspect of growth: increased tissue mass without an increase in cell number [38]. In the rats between 0 and 20 days old, all organs grow by cell division only, whereas between 21 and 42 days, most organs, including striated skeletal muscle, grow by both cellular hyperplasia and hypertrophy; between 64 and 86 days, all organs grow by cellular hyperplasia [38]. Physiological alterations during the hyperplastic and/or hypertrophic growth of an organ may result in changes in the number and/or size of the cells in the organ.

Therefore, in the present study, the protein, DNA content and protein/DNA ratio in the gastrocnemius muscle were analyzed. The alloxan group that was subjected to the continuous training showed higher DNA content and lower protein/DNA ratios than that of the intermittent training alloxan group, which indicates that continuous training was effective in promoting muscle hyperplasia, whereas intermittent training resulted in greater muscle hypertrophy. In previous studies, it was showed that exercise training increased serum and muscle IGF-1 concentrations in diabetic rats [47-50]. Thus, in the present study, the alterations in muscle mass in 


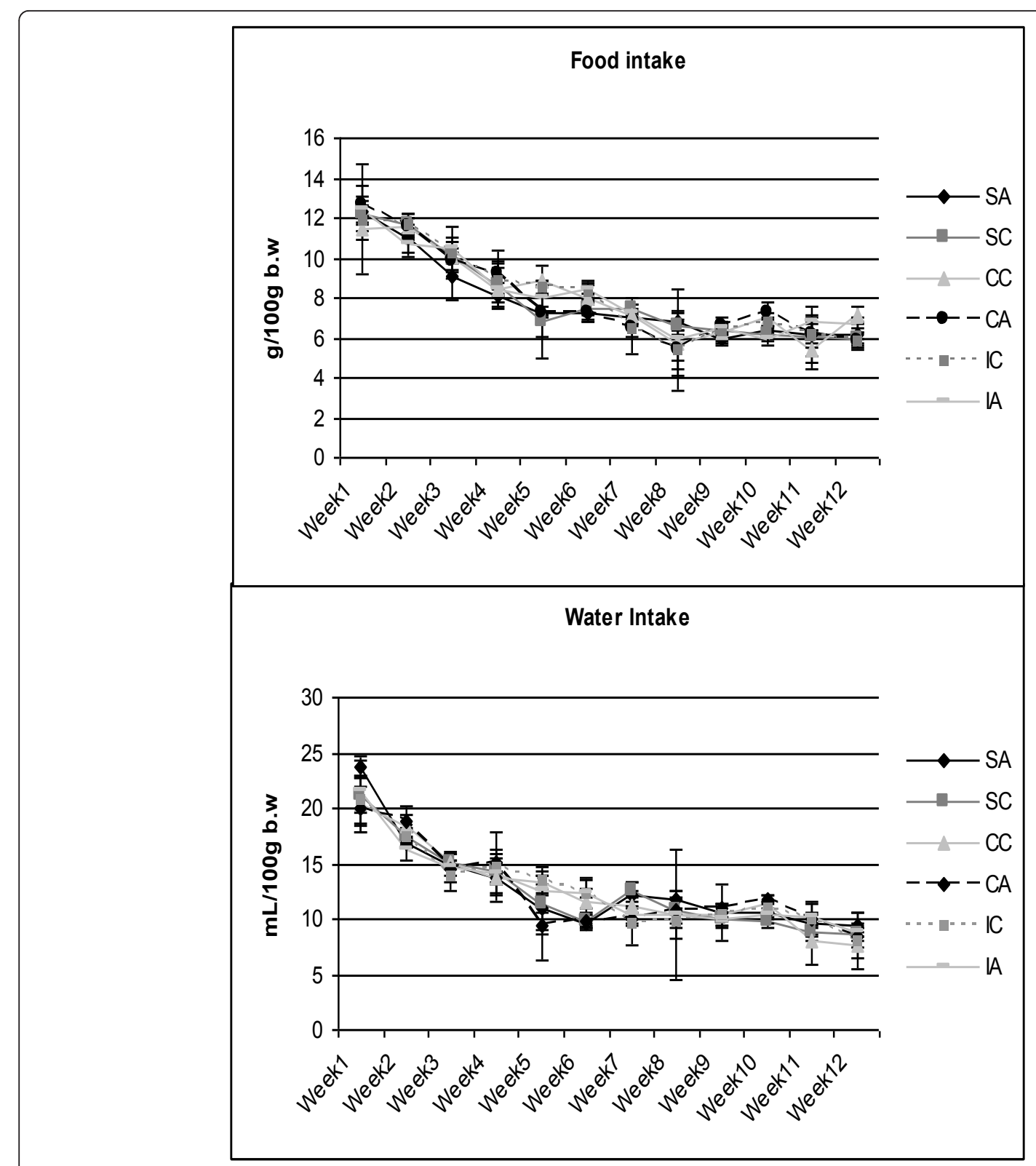

Figure 4 Food intake and water intake of the animals at weaning (28 days) until the end of the experiment (120 days). Results are expressed as means \pm standard deviation of 10 animals per group. SA: Sedentary alloxan, SC: Sedentary control, CC: Continuous training control, CA: Continuous training alloxan, IC: Intermittent training control and IA: Intermittent training alloxan.

Table 1 Fasting (12 hs) and non fasting (after glucose overload) serum glucose and insulin levels at weaning (28 days).

\begin{tabular}{ccc}
\hline 28 days & Alloxan & Control \\
\hline Fasting serum glucose $(\mathrm{mg} / \mathrm{dL})$ & $82.1 \pm 8.6$ & $81.8 \pm 6.7$ \\
Non fasting serum glucose $(\mathrm{mg} / \mathrm{dL})$ & $200.6 \pm 35.0 *$ & $155.3 \pm 11.2$ \\
Fasting insulin level $(\mathrm{ng} / \mathrm{mL})$ & $0.43 \pm 0.27$ & $0.61 \pm 0.41$ \\
Non Fasting insulin level $(\mathrm{ng} / \mathrm{mL})$ & $0.84 \pm 0.39$ & $0.79 \pm 0.48$ \\
\hline
\end{tabular}

Results are expressed as means \pm standard deviation of 10 animals per group. *, statistically significant different (student test, $p<0.05$ ) from control group. the alloxan groups after exercise training could be related to a possible increase in IGF-1 levels.

In an attempt to elucidate the possible mechanisms involved in cellular growth alterations in skeletal muscle that are induced by exercise training, protein synthesis and degradation rates were evaluated in the soleus muscle, but no differences were observed among the groups. Fedele et al. [28] also found no change in muscle protein synthesis in diabetic rats after acute resistance training. On the other hand, Farrell et al. [51] showed 
Table 2 Fasting (12 hs) and non fasting (after glucose overload) serum glucose and insulin levels at 120 days.

\begin{tabular}{|c|c|c|c|c|c|c|}
\hline 120 days & SA & SC & $\mathrm{CC}$ & $\mathrm{CA}$ & IC & IA \\
\hline Fasting serum glucose $(\mathrm{mg} / \mathrm{dL})$ & $\begin{array}{l}79.38 \\
\pm 6.62\end{array}$ & $\begin{array}{l}78.93 \\
\pm 3.54\end{array}$ & $\begin{array}{l}75.83 \\
\pm 4.28\end{array}$ & $\begin{array}{l}77.61 \\
\pm 4.28\end{array}$ & $\begin{array}{l}78.00 \\
\pm 7.05\end{array}$ & $\begin{array}{l}77.74 \\
\pm 5.96\end{array}$ \\
\hline Non fasting serum glucose (mg/dL) & $132.03 \pm 16.38$ & $\begin{array}{l}115.74 \\
\pm 5.16\end{array}$ & $\begin{array}{l}118.77 \\
\pm 8.07\end{array}$ & $\begin{array}{r}124.42 \\
\pm 13.17\end{array}$ & $\begin{array}{r}105.42 \\
\pm 5.41\end{array}$ & $125.44 \pm 18.80^{f}$ \\
\hline $\begin{array}{l}\text { Fasting insulin level } \\
\qquad(\mathrm{ng} / \mathrm{mL})\end{array}$ & $\begin{array}{c}0.84 \\
\pm 0.61\end{array}$ & $\begin{array}{l}1.90 \\
\pm 1.04\end{array}$ & $\begin{array}{l}2.10 \\
\pm 1.59\end{array}$ & $\begin{array}{c}0.72 \\
\pm 0.44\end{array}$ & $\begin{array}{l}1.28 \\
\pm 1.00\end{array}$ & $\begin{array}{l}1.53 \\
\pm 0.94\end{array}$ \\
\hline $\begin{array}{l}\text { Non fasting insulin level } \\
\qquad(\mathrm{ng} / \mathrm{mL})\end{array}$ & $\begin{aligned} & 3.72 \\
\pm & 2.71\end{aligned}$ & $\begin{array}{r}2.74 \\
\pm 1.98\end{array}$ & $\begin{array}{r}2.29 \\
\pm 1.66\end{array}$ & $\begin{array}{l}1.97 \\
\pm 1.40\end{array}$ & $\begin{array}{r}3.96 \\
\pm 2.55\end{array}$ & $\begin{aligned} & 3.71 \\
\pm & 1.85\end{aligned}$ \\
\hline
\end{tabular}

Results are expressed as means \pm standard deviation of 10 animals per group. SA: Sedentary alloxan, SC: Sedentary control, CC: Continuous training control, CA: Continuous training alloxan, IC: Intermittent training control and IA: Intermittent training alloxan. Letter indicate a statistically significant difference among groups (Two- way ANOVA $(3 \times 2)$ and Bonferroni post hoc test, $p<0.05)$ referring to non-fasting serum glucose. f, statistically significant difference for IA vs. IC.

Table 3 Static insulin secretion (ng/5 islets $\times \mathrm{h}$ ) by the isolated pancreatic islets in response to different glucose concentrations $(2$

\begin{tabular}{ccccccc}
\hline Glucose Concentration & SA & SC & CC & CA & IC & IA \\
\hline $2.8 \mathrm{mM}$ & $0.92 \pm 0.17^{\mathrm{a}}$ & $1.56 \pm 0.40$ & $1.52 \pm 0.36$ & $1.32 \pm 0.44$ & $0.63 \pm 0.28^{\mathrm{h}, \mathrm{i}}$ & $1.97 \pm 0.48^{\mathrm{c}, \mathrm{d}, \mathrm{f}}$ \\
$11.1 \mathrm{mM}$ & $10.65 \pm 3.76^{\mathrm{a}}$ & $25.00 \pm 6.08$ & $26.36 \pm 7.76$ & $17.43 \pm 3.13^{\mathrm{e}}$ & $4.69 \pm 2.28^{\mathrm{h}, \mathrm{i}}$ & $5.94 \pm 2.60^{\mathrm{d}}$ \\
\hline
\end{tabular}

Results are expressed as means \pm standard deviation of 10 animals per group. SA: Sedentary alloxan. SC: Sedentary control. CC: Continuous training control. CA: Continuous training alloxan. IC: Intermittent training control and IA: Intermittent training alloxan. Letter indicate a statistically significant difference among groups (Two- way ANOVA $(3 \times 2)$ and Bonferroni post hoc test. $p<0.05)$ referring to non fasting serum glucose. a. statistically significant difference for SA vs SC; $C$. statistically significant difference for $S A$ vs IA; $d$. statistically significant difference for CA vs IA; e. statistically significant difference for CA vs CC; f. statistically significant difference for IA vs. IC; h. statistically significant difference for SC vs IC; i. statistically significant difference for CC vs IC.

Table 4 Total serum protein and albumin levels, protein level, DNA content and the protein/DNA ratio in the gastrocnemius muscle of the animals at 120 days.

\begin{tabular}{|c|c|c|c|c|c|c|}
\hline & SA & SC & $\mathrm{CC}$ & CA & IC & IA \\
\hline $\begin{array}{c}\text { Total serum protein } \\
(\mathrm{g} / \mathrm{L})\end{array}$ & $\begin{array}{c}7.08 \\
\pm 0.08\end{array}$ & $\begin{array}{c}7.05 \\
\pm 0.22\end{array}$ & $\begin{array}{c}7.12 \\
\pm 0.16\end{array}$ & $\begin{array}{c}7.20 \\
\pm 0.13\end{array}$ & $\begin{array}{c}7.17 \\
\pm 0.18\end{array}$ & $\begin{array}{c}7.19 \\
\pm 0.11\end{array}$ \\
\hline $\begin{array}{l}\text { Serum albumin } \\
(\mathrm{g} / \mathrm{L})\end{array}$ & $\begin{aligned} & 4.78 \\
\pm & 0.37\end{aligned}$ & $\begin{array}{c}4.82 \\
\pm 0.28\end{array}$ & $\begin{aligned} & 4.98 \\
\pm & 0.36\end{aligned}$ & $\begin{array}{c}4.87 \\
\pm 0.45\end{array}$ & $\begin{array}{c}5.04 \\
\pm 0.36\end{array}$ & $\begin{array}{c}5.33 \\
\pm 0.86\end{array}$ \\
\hline $\begin{array}{l}\text { Protein gastrocnemius } \\
\qquad(\mathrm{mg} / 100 \mathrm{mg})\end{array}$ & $\begin{array}{l}6.01 \\
\pm 1.37\end{array}$ & $\begin{array}{l}6.09 \\
\pm 0.86\end{array}$ & $\begin{array}{c}6.51 \\
\pm 1.25\end{array}$ & $\begin{array}{c}5.39 \\
\pm 1.32\end{array}$ & $\begin{array}{c}5.55 \\
\pm 1.22\end{array}$ & $\begin{array}{l}6.38 \\
\pm 0.81\end{array}$ \\
\hline $\begin{array}{l}\text { DNA gastrocnemius } \\
(\mathrm{mg} / 100 \mathrm{mg})\end{array}$ & $0.053 \pm 0.013$ & $\begin{array}{l}0.058 \\
\pm 0.010\end{array}$ & $0.069 \pm 0.016$ & $0.071 \pm 0.021$ & $\begin{array}{c}0.051 \\
\pm 0.012\end{array}$ & $\begin{aligned} & 0.050 \\
\pm & 0.016^{\mathrm{d}}\end{aligned}$ \\
\hline Protein/DNA gastrocnemius & $\begin{array}{r}110.35 \\
\pm 20.37\end{array}$ & $\begin{array}{r}108.02 \\
\pm 27.80\end{array}$ & $\begin{array}{r}95.35 \\
\pm 15.17\end{array}$ & $\begin{array}{r}84.95 \\
\pm 37.15\end{array}$ & $\begin{array}{r}115.61 \\
\pm 39.29\end{array}$ & $\begin{array}{r}146.27 \\
\pm 69.28^{\mathrm{d}}\end{array}$ \\
\hline
\end{tabular}

Results are expressed as means \pm standard deviation of 10 animals per group. SA: Sedentary alloxan, SC: Sedentary control, CC: Continuous training control, CA: Continuous training alloxan, IC: Intermittent training control and IA: Intermittent training alloxan. Letter indicate a statistically significant difference among groups (Two- way ANOVA $(3 \times 2)$ and Bonferroni post hoc test, $\mathrm{p}<0.05)$ referring DNA and Protein/DNA ratio. d, statistically significant difference for CA vs. IA.

Table 5 Protein synthesis and degradation in the soleus muscle of the animals at 120 days.

\begin{tabular}{ccccccc}
\hline & SA & SC & CC & CA & IC & IA \\
\hline Protein synthesis & 11.06 & 12.77 & 19.40 & 13.68 & 14.46 & 11.14 \\
(pmol/mg.h) & \pm 2.21 & \pm 5.76 & \pm 3.82 & \pm 6.37 & \pm 2.59 & \pm 2.21 \\
$\quad$ Protein & 350.56 & 287.93 & 271.29 & 244.04 & 387.00 & 322.49 \\
degradation & \pm 90.71 & \pm 37.38 & \pm 89.94 & \pm 44.26 & \pm 95.74 & \pm 93.99 \\
(pmol/mg.h) & & & & & &
\end{tabular}

Results are expressed as means \pm standard deviation of 10 animals per group. SA: Sedentary alloxan, SC: Sedentary control, CC: Continuous training control, CA: Continuous training alloxan, IC: Intermittent training control and IA: Intermittent training alloxan. that diabetic rats presented a higher muscle protein synthesis after moderate endurance training.

Compared to aerobic training, which involves mainly oxidative fibers, generates increased mitochondrial activity and has a reduced effect on protein metabolism, high intensity training involves a greater participation of glycolytic type fibers and a greater increase in mass as well as increased protein synthesis. Therefore, in the present study, protein changes may not have been evident after intermittent training because the muscle fibers that were analyzed have predominantly oxidative characteristics. 
In conclusion, neonatal alloxan administration reduced glucose-induced insulin secretion by pancreatic islet. Although the alloxan administered rats did not show overt diabetes mellitus, the glucose homeostasis was impaired, as indicated by their glucose intolerance. The continuous and intermittent training protocols were effective in preventing the reduction in glucose-induced insulin secretion by pancreatic islets of the alloxan administered animals. The continuous training also improved glucose tolerance. Both exercise raining protocols were effective in altering muscle growth by hyperplasia and hypertrophy, respectively, in the alloxan animals. Additional studies are needed to elucidate the possible mechanisms that are involved in these alterations.

\section{List of abbreviations}

T1DM: Type 1 diabetes mellitus; T2DM: Type 2 diabetes mellitus; WL: total weekly training load.

\section{Acknowledgements}

This manuscript was edited by American Journal Experts (key: 5D08-0D25DAC9-4B83-AD04). We thank Clarice Y Sibuya, Eduardo Custódio and José Roberto R. Silva for their excellent technical assistance. This research was supported by the Fundação de Amparo a Pesquisa do Estado de São Paulo (FAPESP, process 09/51538-5), the Coordenação de Aperfeiçoamento de Ensino Superior (CAPES), and the Conselho Nacional de Desenvolvimento Científico e Tecnológico (CNPq)

\section{Authors' contributions}

CR conceived the study, developed the study protocol, reviewed the references, collected and analyzed the data, and wrote the paper. LTC, RAD, MBA, ACG, LPM and GGA, JDB, participated in the design of the study, reviewed the manuscript, collected the data, and collaborated on the biochemical dosages. MARM conceived the study, participated in its design and coordination and helped in the drafting of the manuscript. All authors read and approved the submission of the final manuscript.

\section{Competing interests}

The authors declare that they have no competing interests.

Received: 11 November 2011 Accepted: 6 February 2012

Published: 6 February 2012

\section{References}

1. Snowling NJ, Hopkins WG: Effects of Different Modes of ExerciseTraining on Glucose Control and Risk Factors for Complications in Type 2 Diabetic Patients. Diabetes care 2006, 30:26.

2. American Diabetes Association (ADA): Standards of Medical Care in Diabetes. Diabetes Care 2010, 33(Suppl):62-69.

3. Cimbiz A, Ozay Y, Yurekdeler N, Caycı K, Colak, Caner T, Aksoy C, Uysal H: The effect of long-term exercise training on the blood glucose level and weight in alloxan administered mice. Scientific Research and Essays 2011, 6:66-70.

4. Rossini AA: Autoimmune diabetes and the circle of tolerance. Diabetes 2004, 53:267-75

5. Brownlee M: Biochemistry and molecular cell biology of diabetic complications. Nature 2001, 414:813-821.

6. Ivy JL, Zderic TD, Fogt DL: Prevention and treatment of non-insulindependent diabetes mellitus. Exercise and Sport Sciences Reviews 1999 27:1-35

7. Hayashia T, Hiranoa T, Yanamotoa T, Ito Y, Adachi M: Intensive insulin therapy reduces small dense low-density lipoproteinparticles in patients with type 2 diabetes mellitus: relationship totriglyceride-rich lipoprotein subspecies. Metabolism Clinical and experimental 2006, 55:879-884.
8. Menge BA, Schrader H, Ritter PR, Ellrichmann M, Uhl W, Schmidt WE, Meier JJ: Selective amino acid deficiency in patients with impaired glucose tolerance and type 2 diabetes. Regul Pept 2010, 160:75-80.

9. Knowler WC, Barrett-connor E, Fowler SE, Hamman RF, Lachin JM, Walker EA, Nathan DM, Diabetes prevention Program Research Group: Reduction in the incidence of type 2 diabetes with lifestyle intervention or metformin. Journal of Medicine 2002, 346:393-403.

10. Lindstrom J, Louheranta A, Mannelin M, Rastas M, Salminen V, Eriksson J, Uusitupa M, Tuomilehto J: Finnish diabetes Prevention Study Group: Lifestyle intervention and 3- year Results on diet and Physical activity. Diabetes care 2003, 26:3230-3236.

11. Li G, Hu Y, Yang W, Jiang Y, Wang J, Xiao J, Hu Z, Pan X, Howard BV, Bennett PH: Effects of insulin resistance and insulin secretion on the efficacy of interventions to retard development of type 2 Diabetes Mellitus. Diabetes Research Clinical Practice 2002, 58:193-200.

12. Oliveira CAM, Luciano E, Marcondes MCCG, Mello MAR: Effects of swimming training at the intensity equivalent to aerobic/anaerobic metabolic transition in alloxan diabetic rats. Journal of Diabetes and its Complications 2007, 21:258-264

13. Gomes RJ, Leme JACA, Moura LP, Araújo MB, Rogatto GP, Moura RF, Luciano E, Mello MAR: Growth factors and glucose homeostasis in diabetic rats: effects of exercise training. Cell Biochemistry and Function 2009, 2:195-201.

14. Ribeiro C, Mota CSA, Voltarelli FA, Araújo MB, Botezelli JD, Oliveira CAM, Mello MAR: Effects of Moderate Intensity Physical Training in Neonatal Alloxan- Administered Rats. Journal of diabetes and metabolism 2010, 1:1-5.

15. Mrozikiewicz A, Kielczewska-Mrozikiewicz D, Lowicki Z, Chimara E, Korzeniowska K, Mrozikiewicz PM: Blood levels of alloxan in children with insulin-dependent diabetes mellitus. Acta Diabetologica 1994, 31:236-7.

16. Rerup CC: Drugs producing diabetes through damage of the insulin secreting cells. Pharmacol Rev 1970, 22:485-518.

17. Bonnerweir S, Smith FE: Islet cell growth and the growth factors involved Trends in endocrinology and metabolism 1994, 2:60-64.

18. Portha B, Blondel O, Serradas P, McEvoy R, Giroix MH, Kergoat M, Bailbe D: The rat models of non-insulin dependent diabetes induced by neonatal streptozotocin. Diabetes \& Metabolism 1989, 31:61-75.

19. Takada J, Machado MA, Peres SB, Brito LC, Borges-Silva CN, Costa CEM, Fonseca-Alaniz MH, Andreotti S, Lima FB: Neonatal streptozotocin-induced diabetes mellitus: a model of insulin resistance associated with loss of adipose mass. Metabolism Clinical and Experimental 2007, 56:977-984.

20. Portha B, Picon L, Rosselin G: Chemical diabetes in the adult rat as the spontaneous evolution neonatal diabetes. Diabetologia 1979, 17:371-377.

21. Kodama $T$, Iwase $M$, Nunoi $K$, Maki Y, Yoshinari M, Fujishima M: A new diabetes model induced by neonatal alloxan treatment in rats. Diabetes Research and Clinical Practice 1993, 20:183-189.

22. Oliveira CAM, Luciano E, Mello MAR: The role of exercise on long- term effects of alloxan administered in neonatal rats. Experimental Physiology 2004, 90:79-86.

23. Contarteze RVL, Mota CSA, Oliveira CAM, Leme JACA, Bottcher LB, Mello MAR, Luciano E: Exercise test and glucose homeostasis in rats treated with alloxan during the neonatal period or fed a high calorie diet. Journal of Diabetes 2009, 1:65-72.

24. Ribeiro C, Oliveira CAM, Luciano E, Mello MAR: Diabetes evolution in rats after neonatal treatment with alloxan. Research Communications in Molecular Pathology and Pharmacology 2005, 7:177-178.

25. Luciano E, Mello MAR: Efeitos do exercício físico crônico sobre as proteínas no diafragma de ratos diabéticos. Motriz 1999, 5:146-151.

26. Leme JACA, Araújo MB, Moura LP, Gomes RJ, Moura RF, Rogatto GP, Mello MAR, Luciano E: Effects of physical training on serum and pituitary growth hormone contents in diabetic rats. Pituitary 2009, 4:304-308.

27. Fujimoto E, Machida S, Higuchi M, Tabata I: Effects of nonexhaustive bouts of high-intensity intermittent swimming training on GLUT-4 expression in rat skeletal muscle. The Journal of Physiological Science 2009, 60:95-101.

28. Fedele MJ, Hernandez JM, Lang CH, Vary TC, Kimball SR, Jefferson LS, Farrell PA: Severe diabetes prohibits elevations in muscle protein synthesis after acute resistance exercise in rats. Journal of Applied Physiology 2000, 88:102-108.

29. Luciano E, Lima FB: Metabolismo de ratos diabéticos treinados submetidos ao jejum e ao exercício agudo. Revista de Ciências Biomédicas 1997, 18:47-60. 
30. Gobatto CA, Mello MAR, Sibuya CY, de Azevedo JR, dos Santos LA, Kokubun E: Maximal lactate steady state in rats submitted to swimming exercise. Comparative Biochemistry and Physiology 2001, 130:21-27.

31. Braga $L R$, Mello MAR, Gobatto CA: Exercício contínuo e intermitente: efeitos do treinamento e do destreinamento sobre a gordura corporal de ratos obesos. Archivos Latinoamericanos de Nutrición 2004, 54:58-65.

32. Voltarelli FA, Mello MAR, Gobatto CA: Determination of anaerobic threshold in rats using the lactate minimum test. Brazilian Journal of Medical and Biological Research, Ribeirão Preto/SP 2002, 35:1389-1394.

33. Cambri LT, Dalia RA, Ribeiro C, Mello MAR: Aerobic capacity of rats recovered from fetal malnutrition with a fructose-rich diet. Applied Physiology, Nutrition, and Metabolism 2010, 35:490-497.

34. Araújo GG, Papoti M, Manchado-Gobatto FB, Mello MAR, Gobatto CA: Padronização de um Protocolo Experimental de Treinamento Periodizado em Natação Utilizando Ratos Wistar. Revista Brasileira de Medicina do Esporte 2010, 16:51-56.

35. Cinti S: The adipose organ. Prostagl Leukotr Essent Fatty Acids 2005, 73:9-15.

36. Lowry $\mathrm{OH}$, Rosebroug NJ, Farr AL, Randall RT: Protein measurement with the folinphenol reagent. J Biol Chem 1951, 93:265-275.

37. Giles KW, Mayers A: An improved diphenylamine method for the estimation of deoxyribonucleic acid. Nature 1965, 206:93.

38. Winick M, Basel JA, Bosso PA: A nutrition and cell growth.Edited by: Winick M. Nutrition and development. New York; 1972:49-97.

39. Fulks RM, Li JB, Goldberg AL: Effects of insulin, glucose, and amino acids on protein turnover in rat diaphragm. J Biol Chem 1975, 250:290-298.

40. Waalkes TP, Udenfriend S: Tyrosine in plasma and tissues. J Lab Clin Med 1957, 50:733-736.

41. Lacy PE, Kostianovsky M: Method for isolation of the intact islets of Langerhans from the rat pancreas. Diabetes 1967, 16:35.

42. Gallagher D, Kelley DE, Yim JE, Spence N, Albu J, Boxt L, Pi-Sunyer FX, Heshka S: Adipose tissue distribution is different in type 2 diabetes. Am J Clin Nutr 2009, 89:807-14

43. Abate N, Garg A, Peshock RM, Stray-Gundersen J, Adams-Huet B, Grundy SM: Relationship of generalized and regional adiposity to insulin sensitivity in men with NIDDM. Diabetes 1996, 45:1684-93.

44. Ross R, Freeman JA, Janssen I: Exercise alone is an effective strategy for reducing obesity and related comorbidities. Exerc Sport Sci Rev 2000 28:165-170.

45. Hu FB, Manson JE, Stampfer MJ, Colditz G, Liu S, Solomon CG, Willett WC: Diet, lifestyle, and the risk of type 2 diabetes mellitus in women. $N$ Engl J Med 2001, 345:790-797.

46. Leme JACA, Castellar A, Remedio RN, Barbosa RA, Moura LP, Dalia RA, Gomes RJ, Caetano FH, Mello MAR, Luciano E: Efeitos em curto prazo da aplicação de aloxana para indução de diabetes em ratos wistar. Bioscience Journal 2010, 26:451-456.

47. Gomes RJ, Caetano FH, De Mello MAM, Luciano E: Effects of chronic exercise on growth factors in diabetic rats. J Exerc Physiol 2005, 8:16-23.

48. Gomes RJ, Mello MAR, Caetano FH, Sibuya CY, Anaruma CA, Rogatto GP, Pauli JR, Luciano E: Effects of swimming training on bone mass and the GH/IGF-1 axis in diabetic rats. Growth Horm IGF Res 2006, 16:326-331.

49. Gomes RJ, Oliveira CAM, Ribeiro C, Mota CSA, Moura LP, Leme JACA, Luciano E, Mello MAR: Effects of exercise training on hippocampus concentrations of insulin and IGF-1 in diabetic rats. Hippocampus 2009 2:52-59.

50. Leme JA, Silveira RF, Gomes RJ, Moura RF, Sibuya CA, Mello MA, Luciano E: Long-term physical training increases liver IGF-I in diabetic rats. Growth Horm IGF Res 2009, 3:262-266.

51. Farrell PA, Fedele MJ, Vary TC, Kimball SR, Jefferson LS: Effects of intensity of acute-resistance exercise on rates of protein synthesis in moderately diabetic rats. Journal of Applied Physiology 1998, 85:2291-2297.

doi:10.1186/1758-5996-4-5

Cite this article as: Ribeiro et al:: Muscle protein metabolism in neonatal alloxan-administered rats: effects of continuous and intermittent swimming training. Diabetology \& Metabolic Syndrome 2012 4:5.

\section{Submit your next manuscript to BioMed Central and take full advantage of:}

- Convenient online submission

- Thorough peer review

- No space constraints or color figure charges

- Immediate publication on acceptance

- Inclusion in PubMed, CAS, Scopus and Google Scholar

- Research which is freely available for redistribution

Submit your manuscript at www.biomedcentral.com/submit
Ciomed Central 